Article

\title{
Fuel Treatments and Potential Fire Behavior in Peri-Urban Forests in Northern Greece
}

\author{
Theano Samara ${ }^{1, *}$, Dimitrios Raptis ${ }^{2}$ and Ioannis Spanos 1 \\ 1 Forest Research Institute of Thessaloniki, ELGO-DEMETER, 57006 Vassilika, Thessaloniki, Greece; \\ ispanos@fri.gr \\ 2 Laboratory of Forest Management and Economics, Department of Forestry and Natural Environment \\ Management, Technical University of Kavala, 66100 Drama, Greece; d_rapt@yahoo.gr \\ * Correspondence: theasam@fri.gr; Tel.: +30-2310-461-172
}

Received: 6 June 2018; Accepted: 9 July 2018; Published: 10 July 2018

check for updates

\begin{abstract}
The peri-urban and urban forests in Greece occupy a total area of 105.353 ha. In these vulnerable ecosystems, fire constitutes a natural disaster presenting particular challenges and specific difficulties. These include the high number of visitors as well as the forest characteristics, such as the presence of particularly flammable tree species and the high accumulation of combustible biomass, that make the on-start of fires more likely. The main purpose of the current research is to identify the optimum combination of silvicultural treatments to efficiently reduce potential severity of forest fires and to facilitate their successful suppression by firefighting crews. In order to simulate the basic fire environment of urban forests, two main experimental plots were established and several tree and topographical characteristics were measured. Additionally, a crown fire hazard modelling system (NEXUS) was used to simulate forest fire potential behavior before and after the adoption of the silvicultural treatments that altered critical characteristics of the forest fire environment. The results clearly show that specific silvicultural prescriptions altered the type of forest fire spreading potential, revealing the overall efficiency of preventing actions during forest management.
\end{abstract}

Keywords: urban ecosystems; fuel treatments; NEXUS; simulation; fire

\section{Introduction}

For many decades, Greece has encountered the devastating effects of uncontrolled wildfires in terms of human life and property losses, extended soil degradations, and alterations in vegetation composition. During the last 30 years, destructive forest fires burned millions of hectares of forests and forested lands, with the most devastating events occurring in Lesvos in 1982, Samos in 1983, Ikaria in 1993 [1-3], Attika in 1984 [4], Thasos in 1985 and 1989 [5-7], Thessaloniki in 1997 [7,8], Chalkidiki in 1990 and 2006, and Peloponnese and Evia in 2008 [9]. Despite the fact that fires constitute an integral part of the ecosystems in the Mediterranean Basin [10], most of the mitigation efforts has focused on fire suppression after ignition rather than on prevention through fuel management actions. Unlike other parts of the world where a large percentage of fires are naturally caused (especially by lightning), the Mediterranean Basin is marked by the prevalence of human-induced fires. Natural causes are responsible for only a small percentage of all fires (1-5\%) [11].

The peri-urban forests in Greece are very vulnerable to fire occurrence and spread. Covering 105,353 hectares in Greece, the peri-urban forests are mainly a result of afforestation activities by the Forest Service during the 1950s [12]. However, in the Mediterranean Basin, the rapid urban sprawl into bordering forested and agricultural lands led to a new regime of land use intermix which is typical in Mediterranean vegetation, referred to as the wildland-urban interface (WUI) [13-16]. The steady invasion of urban and rural development in wildland areas, as a result of loose policies in Greece, 
increased the fire hazard due to human presence and activity. In this sense, a relationship between the spatial distribution of fire ignition locations and wildland-urban interface has been suggested [17].

Relevant studies have shown that around three-quarters of peri-urban forest fires start in the WUI, and most of them are in areas with a combination of high vegetation and house densities. Moreover, during forest fire advance, the deployment of the suppression forces is based on the protection of human lives and properties, resulting in the burning of high proportions of forested lands $[13,18]$. As a consequence, a great number of mixed ecosystems which are characterized by intense human presence have become increasingly vulnerable to fire [19].

Fires in the peri-urban zone are a complex phenomenon which may lead to uncontrollable aspects of fire behavior. It is a problem that in the last 20 years has become a distinctive and high-importance theme, drawing great interest from scientists and professionals dealing with forest fires worldwide [20-23]. In Greece, fire outbreaks in the suburban zone are very frequent, with 2692 incidents recorded in the Attiki region alone during the period from 2000 to 2011 [24]. The suppression of the suburban fires presents some difficulties which are related to several critical characteristics of the fire environment, such as the increased potentiality of human life and property loss, the disparity of fuel stratum, the magnitude of the potential postfire effects, and the existence of vulnerable infrastructure within the vicinity of a potential fire [25].

The main objective of fuel management is the manipulation of stand characteristics so as to prevent some types of fire which may lead to violent behavior precluding any direct attack from firefighting crews. Reducing the number of stems in a forest stand (thinning), removing understory vegetation (mechanical treatment), and increasing the height to live crown are the basic fuel treatments for lowering fire hazard [26]. In the world literature, a significant number of relevant studies have been contacted assessing the impacts of fuel treatment alternatives for lowering a wildfire's severity [27-32]. Since real experimental fires are difficult to conduct, the assessment of fuel treatments has been mainly based on simulation, using fire models such as FARSITE [33], FlamMap [34], and NEXUS [35] and comparing the expected differences of fire characteristics (flame length, intensity, rate of spread) before and after the treatments [36,37]. However, it is a fact that few studies have evaluated the effects of fuel treatments on fire behavior at the stand level in Mediterranean Basin [38].

The aim of the current study is to evaluate the effects of fuel treatments on fire's front critical characteristics in a peri-urban pine forests in Greece. The research is based on two installed sample plots across two typical peri-urban forests located in Northern Greece. For the needs of the study, the NEXUS forest fire model was used since it implicates basic phases of fire behavior with the possibility of changing inputs related to vegetation attributes and estimating the effects on fire behavior instantly.

\section{Material and Methods}

\subsection{Study Area}

The study areas were located in two urban forests within Thermaikos municipality, $20 \mathrm{~km}$ northwest of Thessaloniki, Greece $\left(40^{\circ} 31^{\prime} \mathrm{N}, 23^{\circ} 37^{\prime} \mathrm{S}\right)$ (Figure 1). The mean elevation is $50 \mathrm{~m}$ above sea level, the average slope is $30 \%$, and the general exposition of the area is east/east west. The climate can be characterized as typical Mediterranean, with the maximum temperature observed during July being $26.6^{\circ} \mathrm{C}$ and the minimum temperature during January being $5.2{ }^{\circ} \mathrm{C}$. The annual mean temperature exceeds $20^{\circ} \mathrm{C}$ and the mean relative humidity is about $78.11 \%$ (Source: Meteorological Station "Macedonia" Airport of Thessaloniki). According to the same station, the annual rainfall is $431.5 \mathrm{~mm}$ per year and the wind direction is unstable following different directions each season, starting from the north during winter, from southwest during spring, and from north and southwest during summer. The geological formations of the area are composed of crystalline structures and sedimentary rocks. The overstory vegetation consists of flammable pine species (Pinus halepensis and Pinus brutia), typical in the Mediterranean region, mixed with some individuals of cypress (Cupressus sempervirens) across the roadsides. The specific pine species are characterized as fire resilient due 
to post fire ability to regenerate naturally, but the crown's lower dead parts and the low levels of moisture content make them prone to crown fires. The understory vegetation is composed by shrubby vegetation of kermes oak (Quercus coccifera), while Rosa sp., Rubus canescens, Ramnus rupestris, and Asparagus sp. may be present in some restricted locations. The herbaceous vegetation consists of the species Phragmites communis, Typha angustifolia, and Xanthium strumarium.

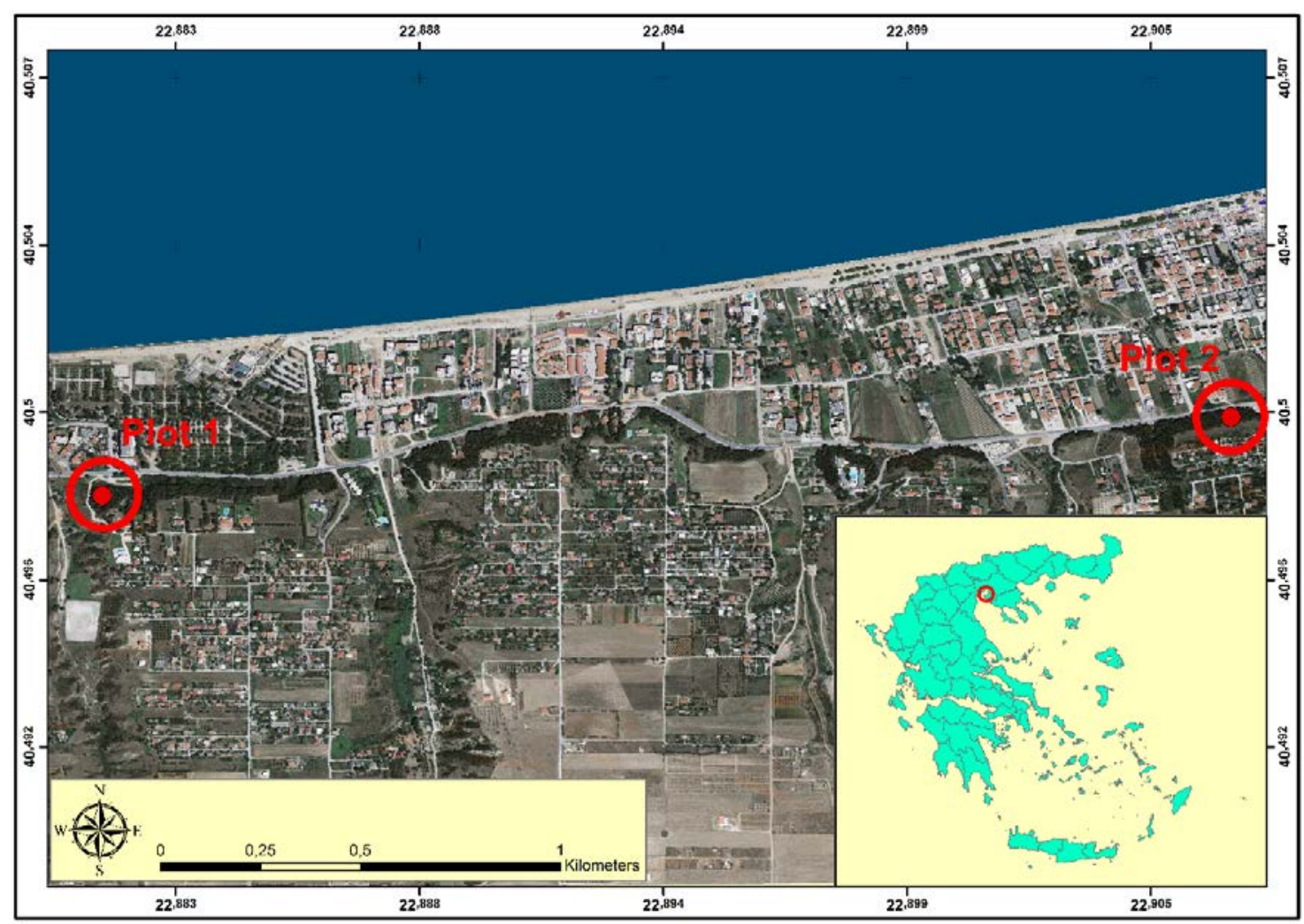

Figure 1. General orientation map of the study area.

\subsection{Experimental Design and Sampling}

At first stage, the boundaries of two different forest parts were digitized in a GIS environment, creating two different strata. These two parts were selected for their different structure as two representative types of peri-urban forests. The first forest part (plot 1) was characterized by medium- and small-sized trees, sparse canopy, and dense understory vegetation, and the second part (plot 2) by dense canopy and pine litter in the surface layer. Using the random points module of ArcGis (10.2), two randomly selected points were chosen and two sample plots were installed, one for each forest part, covering a total area of $500 \mathrm{~m}^{2}$ each. The shape of the plots was rectangular $(20 \times 25 \mathrm{~m})$, vertical to slope direction.

The basic steps of the followed methodology are depicted in the flowchart in Figure 2. Within each sample plot, a number of tree attributes and surface properties were evaluated in order to create the fire environment in detail (Figures 3-5). At the first plot, no fuel treatment was installed, while at the second plot, the surface vegetation was removed mechanically (mechanical clearcutting) and the lower parts of tree's crowns were cut and removed (mechanical pruning) to the height of $2 \mathrm{~m}$ from the ground by the responsible local authorities (Figures 3 and 4).

In both plots, a number attributes at tree and stand level were estimated using laser rangefinders, such as the total number of trees per hectare, the total tree height $(\mathrm{H})$, the canopy base height $(\mathrm{CBH})$, the crown radius $(\mathrm{m})$, and the diameter at breast height $\left(\mathrm{DBH}_{1.30}\right)$ [39]. The $\mathrm{CBH}$ corresponds to the average distance between the lowest continuous live or dead branches of the tree canopy down to 
the ground [40]. Using a spherical densitometer and a Meridian clinometer, the canopy cover and the slope of each plot was estimated, respectively [41]. In addition, five randomly selected squared subplots $(1 \times 1 \mathrm{~m})$ per experimental plot were established, where surface fuel loading was evaluated via a destructive sampling method (Figure 5). The randomness was ensured by creating a topical axes system and selecting randomly (using a random number generator) 2 integral numbers (from 1 to 20 and 1 to 25) as coordinates indicating the subplot's right corner, vertical to slope direction. Surface samples were transported to the laboratory in airtight containers, weighed, oven-dried for $24 \mathrm{~h}$ at $105^{\circ} \mathrm{C}$, and then reweighed [9].

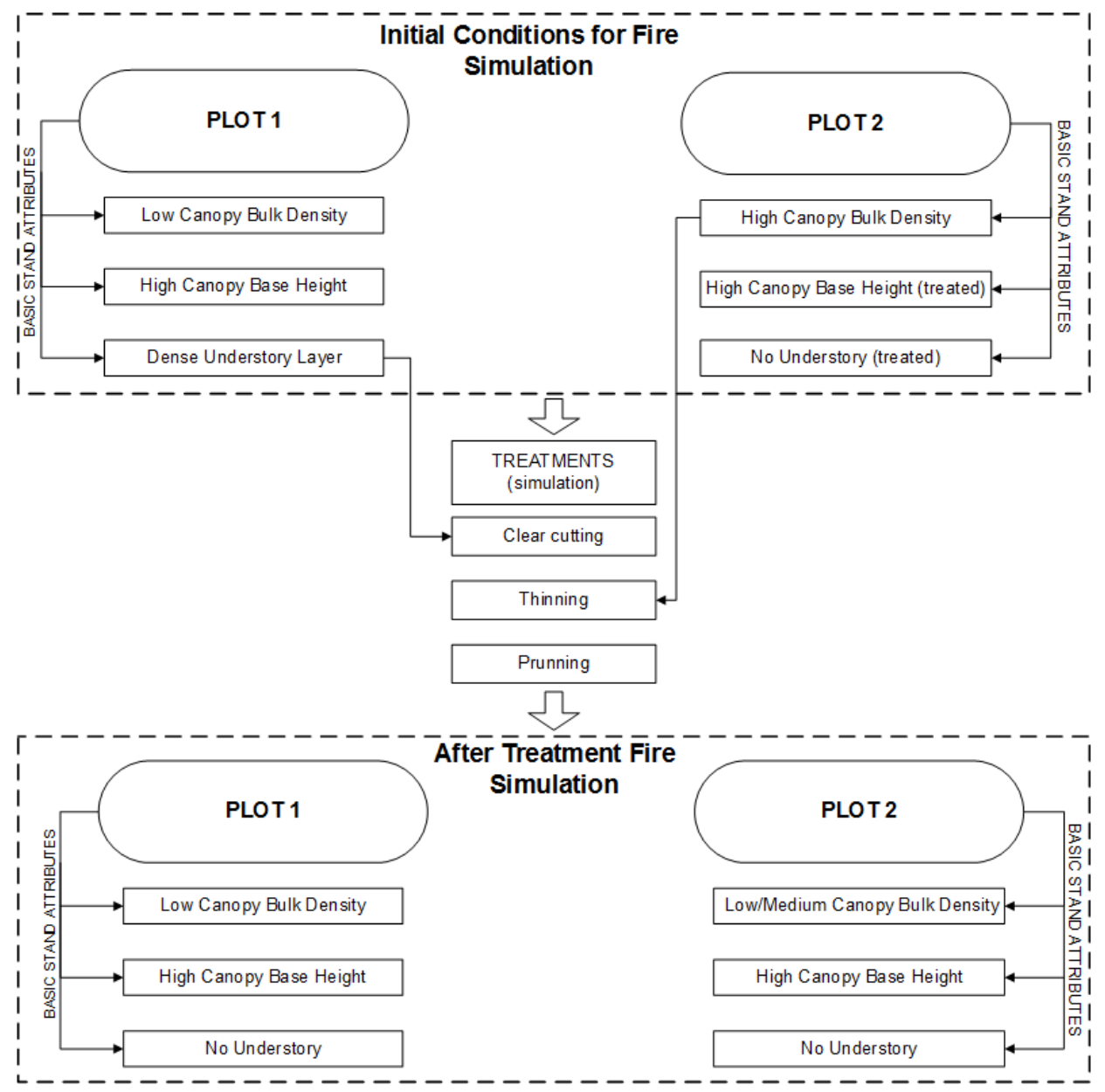

Figure 2. Flowchart of the followed methodology.
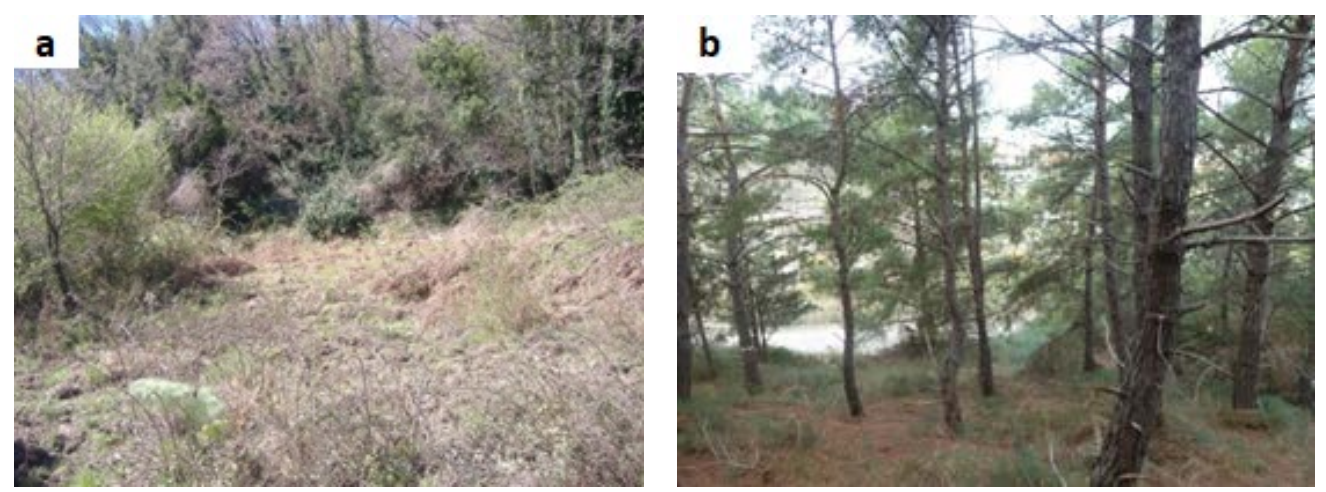

Figure 3. Photos of typical forest structure of the two experimental plots (a) Plot 1 and (b) Plot 2. 

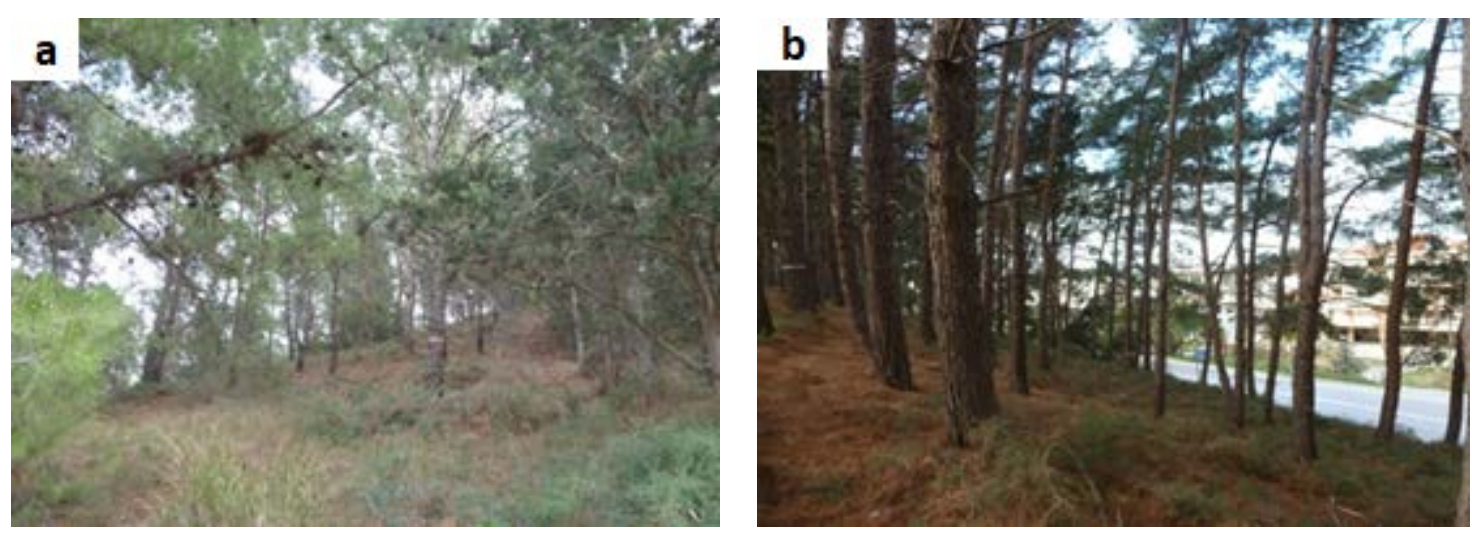

Figure 4. Photos of the two experimental plots (a) Plot 1 and (b) Plot 2.

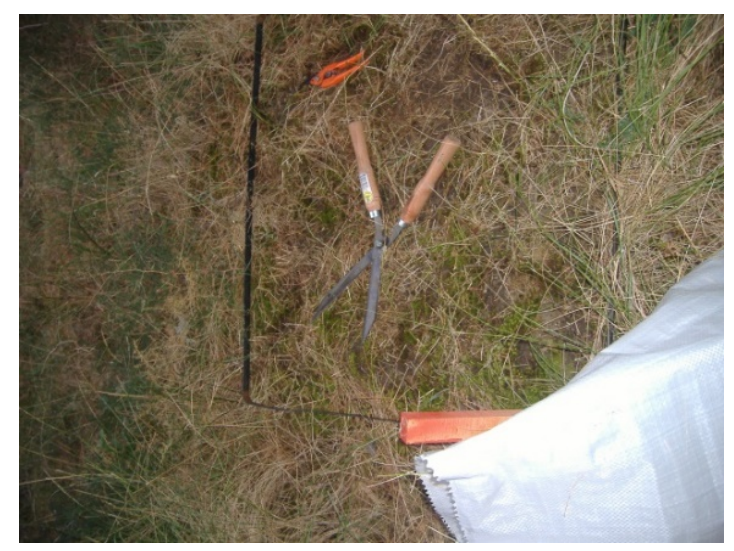

Figure 5. Collecting plant debris and plants in the square plot.

\subsection{Fuel Characteristics}

\subsubsection{Aerial Fuel}

The allometric equations for Pinus halepensis Mill. proposed by Mitsopoulos and Dimitrakopoulos [42] were used for the estimation of the total canopy fuel load (CFL). Based on the above equations, the available crown fuel load (needles and branches $0.0-0.63 \mathrm{~cm}$ ) for each tree was calculated. The CFL was estimated by summing the available fuel load of each tree and dividing it by the area occupied by each experimental plot $\left(500 \mathrm{~m}^{2}\right)$. The total above ground biomass fuel was considered to be uniformly distributed and continuous. Also, the canopy bulk density (CBD) was estimated by dividing CFL by the average canopy length of the individuals of each sample plot $[43,44]$.

\subsubsection{Surface Fuel}

The data obtained from the installed subsample plots led to the creation of custom fuel models for the area, following the methodology proposed by Scott and Burgan [45] and the NEWMDL tool of the BEHAVE modelling system [26]. Surface fuels were divided into four classes based on the diameter of each component $(1 \mathrm{~h}, 10 \mathrm{~h}, 100 \mathrm{~h}$, and $1000 \mathrm{~h})$. The surface per volume ratio $\left(\mathrm{SAV}-\mathrm{m}^{2} / \mathrm{m}^{3}\right)$, the heat content $(\mathrm{kj} / \mathrm{kg})$, and the extinction moisture were obtained from Dimitrakopoulos and Papaioannou [46], Fire Star [47], and Bacciu [48].

\subsubsection{Simulation}

The NEXUS modelling system has been widely used by many researchers to evaluate the effectiveness of fuel treatment scenarios. It provides the possibility of calculating key indicators, such as 
torching index (TI) and crowning index (CI), that allow the direct comparison of the effectiveness of various possible scenarios arising from silvicultural treatments [35]. The NEXUS modelling system, from the array of available models, couples the most widely used for this analysis: Rothermel's surface [49] and crown fire models [50] and Van Wagner's models [51] of transition to crown fire [52-54].

\subsubsection{Silvicultural Treatments}

For the initial simulation of the potential fire behavior in the untreated plots, the current conditions of fuel regime were used as inputs in order to estimate critical characteristics of the fire front, namely, the rate of spread $(\mathrm{m} / \mathrm{min})$, the fireline intensity $(\mathrm{kW} / \mathrm{m})$, the flame length $(\mathrm{m})$, and the crowning index $(\mathrm{km} / \mathrm{h})$. The fuel treatments were applied virtually by reducing the corresponding dendrometric characteristics according to fuel treatment effects, without altering the weather and the topographical conditions. The mechanical removal of the surface vegetation (clearings) was simulated in the first plot by replacing surface fuel load with pine litter and debris, which was obtained by plot 2. Furthermore, the thinning effects were applied virtually in plot 2 only by reducing the basal area and the corresponding canopy fuel load to $25 \%$ and $50 \%$ from the untreated plot. It was theorized that thinnings would not change the surface fuel load significantly, following the findings of Silva [55] in a Mediterranean-type ecosystem.

\section{Results}

Table 1 presents the main physical and chemical properties of the mean values of total surface fuels in each plot. The properties for each fuel model are described in detail by Rothermel [48] and Fire Star [46]. The mean value of litter's surface biomass measured in the first experimental plot surface was $1640 \mathrm{~kg} / \mathrm{m}^{2}$ and for the second experimental plot was $2020 \mathrm{~kg} / \mathrm{m}^{2}$. The highest values of litter's surface load on the second plot may be attributed to the clearings effects and the remaining biomass during mechanical treatment.

Table 1. Physical and chemical properties of the total sample.

\begin{tabular}{ccc}
\hline \multirow{2}{*}{ Properties } & \multicolumn{2}{c}{ Custom Fuel Model (CFM) } \\
\cline { 2 - 3 } & CFM 1: Shrub (kermesoak) & CFM 2: Pinelitter \\
\hline $1 \mathrm{~h}$ (tonne/ha) & 1.232 & 1.109 \\
$10 \mathrm{~h}$ (tonne/ha) & 0.408 & 0.522 \\
$100 \mathrm{~h}$ (tonne $/ \mathrm{ha})$ & - & 0.389 \\
Live Herbaceous Fuel Load (tonne $/ \mathrm{ha})$ & - & - \\
Live Woody Fuel Load (tonne/ha) & 8.857 & - \\
$1 \mathrm{~h} \mathrm{SA} / \mathrm{V}\left(\mathrm{m}^{2} / \mathrm{m}^{3}\right)$ & 2427 & 6249 \\
Live Herbaceous SA $\left./ \mathrm{V}^{2} / \mathrm{m}^{3}\right)$ & - & - \\
Live Woody SA $/ \mathrm{V}\left(\mathrm{m}^{2} / \mathrm{m}^{3}\right)$ & 5960 & - \\
Fuel Bed Depth $(\mathrm{m})$ & 1.977 & 0.210 \\
Extinction Moisture $(\%)$ & 25 & 35 \\
Dead Heat Content $(\mathrm{kJ} / \mathrm{kg})$ & 19,460 & 22,137 \\
Live Heat Content $(\mathrm{kJ} / \mathrm{kg})$ & 19,460 & - \\
\hline
\end{tabular}

Table 2 presents the main tree attributes that were measured in the field. These values were used as inputs to the NEXUS fire modelling system so as to estimate the potential fire behavior. The fuel moisture content values (percent) by size class for seasonal moisture conditions were calculated using the NEXUS module for estimating moisture content (Table 3) and the "Normal Summer" moisture values as proposed by Rothermel [48]. The shading parameter follows the values obtained from canopy cover estimation (\%).

The simulation results before virtual treatments, for the reference year of 2015, for the first and second experimental plots are presented in Table 4 and Figure 6. 
Table 2. The primary data of the two experimental plots.

\begin{tabular}{ccc}
\hline Caption & Experimental Plot 1 & Experimental Plot 2 \\
\hline Stems per Hectare & 460 & 360 \\
Diameter at Breast Height $(\mathrm{cm})$ & 20.16 & 30.27 \\
Tree Height $(\mathrm{m})$ & 12.27 & 17.19 \\
Basal Area $\left(\mathrm{m}^{2} / \mathrm{ha}\right)$ & 16.16 & 27.40 \\
Crown Radii & 4.19 & 6.5 \\
Canopy Base Height $(\mathrm{m})$ & 4.97 & 10.57 \\
Canopy Fuel Load $\left(\mathrm{kg} / \mathrm{m}^{2}\right)$ & 0.577 & 0.862 \\
Crown Bulk Density $\left(\mathrm{kg} / \mathrm{m}^{3}\right)$ & 0.079 & 0.134 \\
\hline
\end{tabular}

Table 3. Weather scenarios and topographical conditions used for the simulation.

\begin{tabular}{cc}
\hline Weather & Inputs \\
\hline Temperature $\left({ }^{\circ} \mathrm{C}\right)$ & $31.5-42.4$ \\
Relative humidity $(\%)$ & $20-25$ \\
Month & August \\
Hemisphere & Northern \\
Time & $15: 00-17: 00$ \\
Wind $(\mathrm{km} / \mathrm{h})$ & 25 \\
Wind direction & Upslope \\
Shading (Canopy Cover-\%) & $>51$ \\
Topography & \\
Slope $(\%)$ & 30 \\
Aspect & East \\
\hline
\end{tabular}

Table 4. Fire behavior according to NEXUS outputs before treatments.

\begin{tabular}{ccc}
\hline \multirow{2}{*}{ Pyric Parameters (before Treatment) } & \multicolumn{2}{c}{ Plot } \\
\cline { 2 - 3 } & $\mathbf{1}$ & $\mathbf{2}$ \\
\hline Fire type & Passive crown fire & Intermediate crown fire \\
Rate of spread $(\mathrm{m} / \mathrm{min})$ & 18.63 & 15.3 \\
Fireline intesity $(\mathrm{kW} / \mathrm{m})$ & 19,153 & 7737 \\
Flame length $(\mathrm{m})$ & 18 & 10.4 \\
Crowning index $(\mathrm{km} / \mathrm{h})$ & 35.6 & 26.4 \\
\hline
\end{tabular}

Note that a passive crown fire is defined as a condition where individual or small groups of trees are burning but solid flame is not maintained in the canopy, whereas intermediate crown fire is a potential type of fire in which conditions for sustained active crown fire spread are met but conditions for crown ignition are not [56].

Based on the mean values of crown width for each tree, it was supposed that the removal of $25 \%$ of the basal area would not reduce canopy cover lower than $50 \%$ and the moisture content of the surface fuels would not be changed significantly. However, during heavy thinning (50\%), the canopy cover is expected to be changed and the fuel moisture content was recalculated by setting the canopy cover lower than $50 \%$. The simulation results after fuel modifications are presented in Table 5 and Figure 6. 
Table 5. Fire behavior according to NEXUS outputs after treatments.

\begin{tabular}{cccc}
\hline Pyric Parameters (after & \multicolumn{3}{c}{ Plot } \\
\cline { 2 - 4 } Treatment) & $\mathbf{1}$ & $\mathbf{2}(\mathbf{2 5} \mathbf{0})$ & $\mathbf{2 ~ ( 5 0 \% )}$ \\
\hline Fire type & Surface fire & Surface fire & Surface fire \\
Rate of spread $(\mathrm{m} / \mathrm{min})$ & 1.46 & 0.81 & 0.87 \\
Fireline intesity $(\mathrm{kW} / \mathrm{m})$ & 149 & 82 & 93 \\
Flame length $(\mathrm{m})$ & 0.8 & 0.6 & 0.6 \\
Crowning index $(\mathrm{km} / \mathrm{h})$ & 35.6 & 33.3 & 44.3 \\
\hline
\end{tabular}

\section{Rate of spread (m/min)}

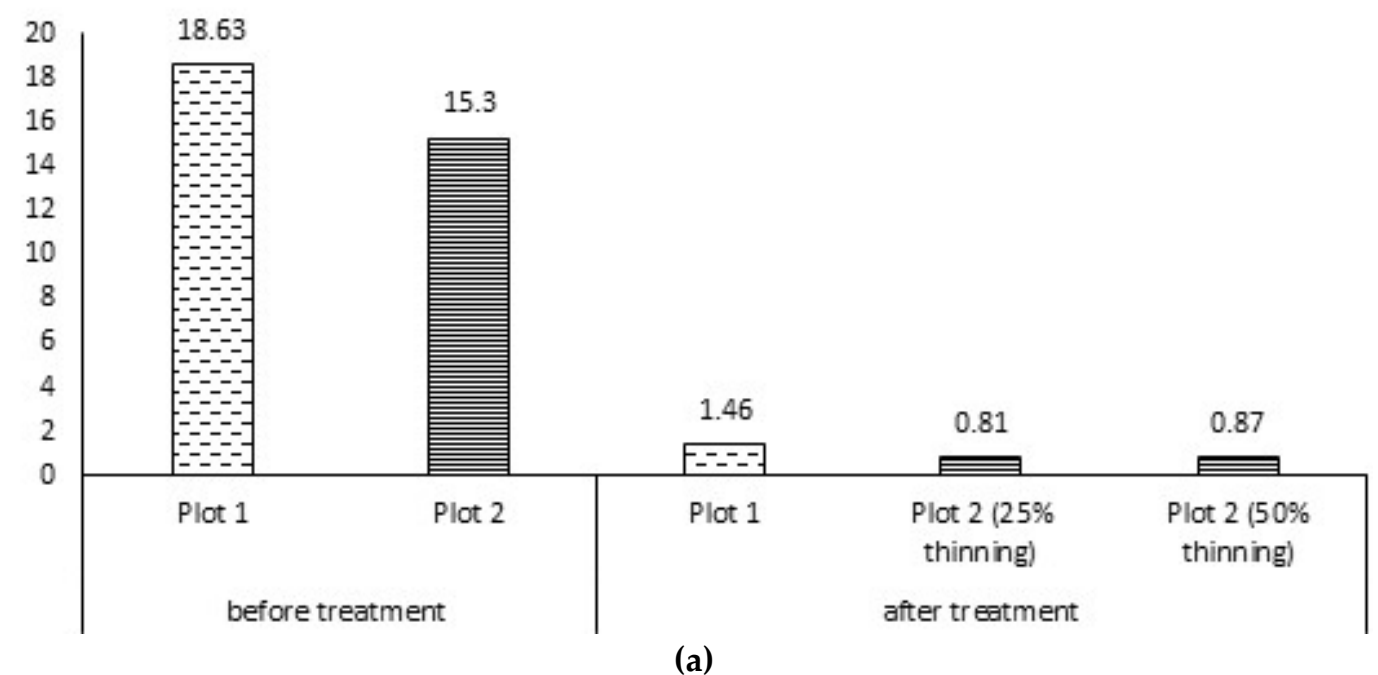

\section{Fireline intesity $(\mathrm{kW} / \mathrm{m})$}

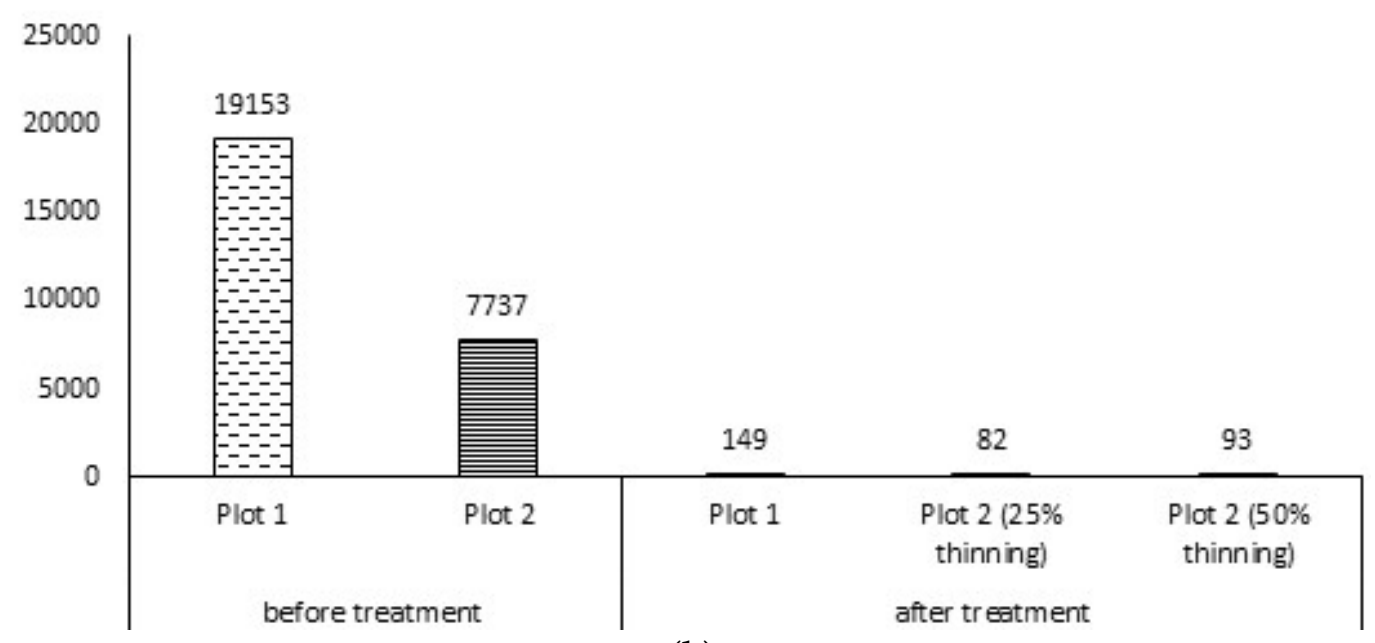

(b)

Figure 6. Cont. 


\section{Flame length (m)}

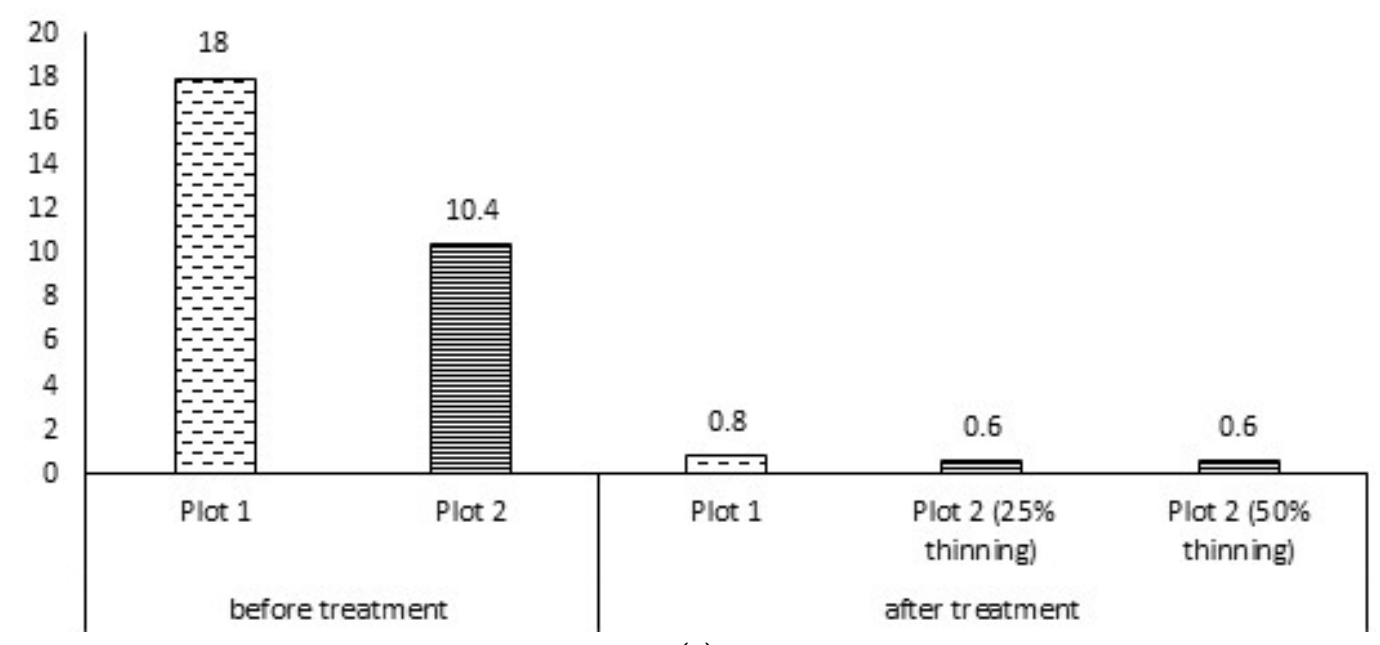

(c)

\section{Crowning index $(\mathrm{km} / \mathrm{h})$}

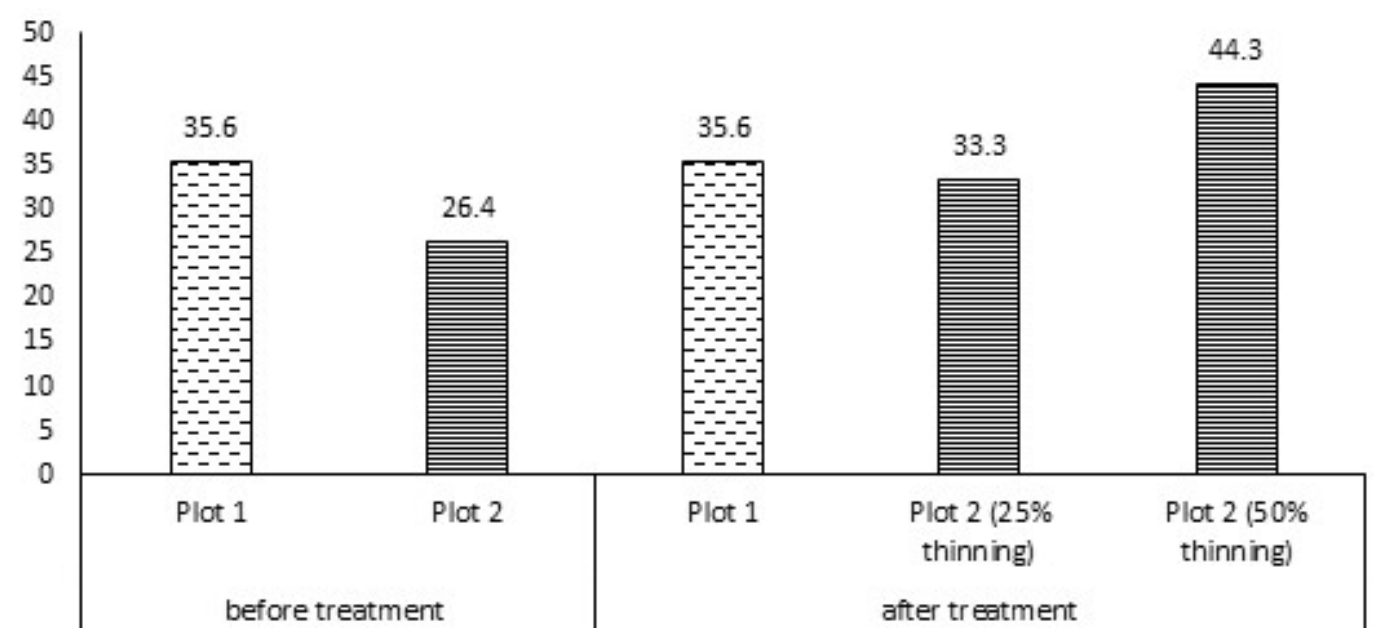

(d)

Figure 6. Critical parameters of the potential fire behavior before and after the simulation. (a) Rate of spread of the flaming front; (b) Fireline intensity (rate of energy or heat release per unit length of the fire front); (c) Flame length; (d) Crowning index (the open $(6.096 \mathrm{~m})$ wind speed at which active crown fire is possible for the specified fire environment).

\section{Discussion}

The design of fire-resilient forest stand structures is one basic management objective in fire prone ecosystems, which is usually based on targeted silvicultural interventions. Thinning, pruning, and understory clearings are the main fuel treatments used by responsible authorities in order to reduce fire hazard in Greece. In any case, the fireline intensity of the flaming front should be lower than $2000 \mathrm{~kW} / \mathrm{m}$ for firefighting crews to launch a successful direct attack, while levels higher than $4000 \mathrm{~kW} / \mathrm{m}$ require indirect methods for suppression [57]. The key element is the prevention of fire from crowning, since crown fire leads to unpredictable and violent behavior [58]. According to the results of the simulation (Table 4), crown ignition was observed in both untreated stands which led to two different types of crown fires, with the fireline intensity to be estimated around 19,153 kW/h in plot 1 and $7737 \mathrm{~kW} / \mathrm{h}$ in plot 2, which actually precluded any direct suppression of the fire's front. After treatment, the fire was retained to the surface layer without crown ignition, resulting in low levels of the critical pyric parameters so as to be easily contained by firefighting forces. Keyes [58] and 
Agee and Skinner [26] defined a set of "firescale principles" in order to reduce crown fire hazard at the stand level. In both studies, it is suggested to reduce surface fuel load to increase the vertical distance of the crown height, to decrease crown density, and to favor large trees in a thinning scenario.

The effects of two of the four proposed principles are assessed in the current research. In plot 1 before treatments, the levels of canopy base height would likely prevent active crowning, but the surface fire in the dense understory resulted in high levels of flame length and intensity due to increased available surface fuel load. After crowning, the fire could not be sustained, advancing as passive crown fire due to low canopy bulk density. On the contrary, in plot 2, the dense canopy provided the necessary fuel for active crowning, which is further verified by the low crowning index, but the reduced surface load due to mechanical treatment prevented the ignition of the low canopy parts. In this experimental plot, foliar ignition is not expected during the early stages of fire as a result of the properties of the understory fuel stratum. However, if foliage ignition occurs at some point within the stand, then intermediate crown fire is expected [56].

The target of the suggested treatments was mainly the crown and the surface layer after the virtual application of thinnings and clearings, respectively. In plot 1, after treatment, clearings reduced the surface load significantly and the potential fire could not be transmitted to the tree foliage. It should be mentioned that in conjunction with a thinning treatment corresponding to $10 \%$ of the basal area, forest managers can achieve even milder combustion conditions that would lead to fires which ground firefighting forces can tackle. However, the low levels of canopy bulk density, below the threshold value of $0.10 \mathrm{~kg} / \mathrm{m}^{3}$ for crown fire cessation [59], led to the hypothesis that there was no need for further thinning. In plot 2, thinning reduced the available aerial fuel load for combustion so that crown fire would not be sustained without high wind speeds. However, intensive thinning may result in increased wind speeds and solar radiation inside the stand, lowering the surface fuel moisture content. Thus, $25 \%$ removal of the initial basal area seems to be effective. Removal of any dead trees, branches, and twigs will improve fuel moisture conditions within the stand, while in final stage, planting with deciduous trees will increase foliar moisture content [36]. Pruning of the lowest points of tree crowns (over $3 \mathrm{~m}$ from ground level) is actually unnecessary due to the high levels of CBH. The combination of silvicultural treatments (thinning and clearings) changed the forest structure, altering the behavior of a potential fire in a Mediterranean environment, as already has mentioned by other authors [36,37]. The results reveal that the fuel treatments had a direct influence upon fire behavior, lowering significantly its potential severity.

\section{Conclusions}

Due to an economic crisis, a small number of forests will receive fuel treatment over their entire area. The decision on where strategic fuel treatment will be more effective in order to reduce wildfire damage, is critical. According to the outcomes of the simulation, a combination of surface and crown fuel reduction treatment is effective for mitigating fires' advance in peri-urban forests. Due to the increasing number of forest fires, the challenges are real and become more important each year. Mediterranean urban forests continue to burn at unprecedented rates, resulting in undesirable landscape patterns and reducing opportunities for restoration. The main challenge is to expand that scale with socially acceptable treatments to sustain these forests.

Author Contributions: T.S., D.R., and I.S. together conceived and designed the Fuel Treatments and Potential Fire Behavior in Peri-Urban Forests, N. Greece. For the case study, T.S. and I.S. performed the calculations and D.R. analyzed the data. T.S., D.R., and I.S. jointly wrote the paper.

Funding: This research received funding from Thermaikos Municipality and Forest Research Institute of Thessaloniki.

Acknowledgments: The authors wish to thank E. Havales for his help with field data. The results published in this paper are part of the research project "Silvicultural treatments of suburban Perea, Ag. Triada, N. Epivates forests of Thermaikos Municipality for protection from fires" supported by Thermaikos Municipality and Forest Research Institute of Thessaloniki. The authors would also wish to thank the two anonymous reviewers for their helpful and constructive comments that greatly contributed to improving the final version of the paper. 
Conflicts of Interest: The authors declare no conflict of interest.

\section{References}

1. Thanos, C.; Marcou, S.; Christodoulakis, D.; Yiannitsaros, S. Early post-fire Regeneration in Pinus brutia forest ecosystem of Samos island (Greece). Acta Oecol. Oec. Plant. 1989, 10, 79-94.

2. Thanos, C.; Marcou, S. Postfire regeneration in Pinusbrutia forest ecosystems of Samos Island (Greece): 6 years after. Acta Oecol. 1991, 10, 633-642.

3. Thanos, C.; Doussi, M. Postfire Regeneration of Pinus brutia Forests, Ecology, Biogeography and Management of Pinus halepensis and Pinus brutia Forest Ecosystems in the Mediterranean Basin; Neeman, G., Trabaud, L., Eds.; Backhuys Publishers: Leiden, The Netherlands, 2000; pp. 291-301.

4. Zagas, T. Research of Pinus halepensis natural regeneration after fire at Mount "Pateras" (Attiki, Greece). Sci. Ann. Fac. For. Nat. Environ. 1987, 11, 303-327.

5. Spanos, I.; Spanos, K. Postfire establishment and survival of Pinus brutia in the island Thasos. In Proceedings of the 2nd Balkan Scientific Conference 'Investigation, Preservation and Utilization of Forest Resources', Sofia, Bulgaria, 3-5 June 1996; Volume 1, pp. 163-168.

6. Spanos, I.; Daskalakou, E.; Thanos, C. Postfire, natural regeneration of Pinus brutia forests in Thasos island, Greece. Act. Oecol. 2000, 21, 13-20. [CrossRef]

7. Spanos, I.; Radoglou, K.; Raftoyiannis, Y. Site quality effects on post-fire regeneration of Pinus brutia forest on a Greek island. Appl. Veg. Sci. 2001, 4, 229-236. [CrossRef]

8. Tsitsoni, T.; Ganatsas, P.; Zagas, T.; Tsakaldimi, M. Dynamics of postfire regeneration of Pinus brutia Ten. in an artificial forest. Plant Ecol. 2004, 171, 165-174. [CrossRef]

9. Spanos, I.; Raftoyannis, Y.; Goudelis, G.; Xanthopoulou, E.; Samara, T.; Tsiontsis, A. Effects of postfire logging on soil and vegetation recovery in a Pinus halepensis Mill. forest of Greece. Plant Soil. 2005, 278, 171-179. [CrossRef]

10. Pausas, J.G.; Vallejo, R. The role of fire in the European Mediterranean ecosystems. In Remote Sensing of Large Wildfires in the European Mediterranean Basin; Chuvieco, E., Ed.; Springer: Berlin, Germany, 1999; pp. 3-16.

11. Alexandrian, D.; Esnault, F.; Calabri, G. Forest fires in the Mediterranean area. In Proceedings of FAO Meeting on Public Policies Affecting Forest Fires; FAO, Ed.; FAO: Rome, Italy, 2008; Available online: http: / / www.fao.org/docrep/x1880e/x1880e07.htm (accessed on 6 June 2018).

12. Christopoulou, O.; Polyzos, S.; Minetos, D. Peri-urban and urban forests in Greece: Obstacle or advantage to urban development? Manag. Env. Qual. 2007, 18, 382-395. [CrossRef]

13. Caballero, D.; Beltran, I.; Velasco, A. Forest Fires and Wildland-Urban Interface in Spain: Types and Risk Distribution. In Proceedings of the 4th International Wildland Fire Conference, Sevilla, Spain, 14-17 May 2007.

14. Lampin-Maillet, C.; Jappiot, M.; Long, M.; Bouillon, C.; Morge, D.; Ferrier, J.-P. Mapping wildland-urban interfaces at large scales integrating housing density and vegetation aggregation for fire prevention in the South of France. J. Environ. Manag. 2010, 91, 732-741. [CrossRef] [PubMed]

15. Badia, A.; Serra, P.; Modugno, S. Identifying dynamics of fire ignition prob-abilities in two representative Mediterranean wildland-urban interface areas. Appl. Geogr. 2011, 31, 930-940. [CrossRef]

16. Galiana-Martin, L.; Herrero, G.; Solana, J. A wildland-urban interface typology for forest fire risk management in Mediterranean areas. Landsc. Res. 2011, 36, 151-171. [CrossRef]

17. Vélez, R. The Causing Factors: A Focus on Economic and Social Driving Forces. In European Forest Institute Discussion Paper 'Living with Wildfires: What Science Can Tell Us'; Birot, Y., Ed.; European Forest Institute: Joensuu, Finland, 2008.

18. Vélez, R. Causes of forest fires in the Mediterranean Basin. In European Forest Institute Discussion Paper 'Risk Management and Sustainable Forestry'; Arbez, M., Birot, Y., Carnus, J.-M., Eds.; European Forest Institute: Joensuu, Finland, 2002.

19. Cochrane, M.A.; Moran, C.J.; Wimberly, M.C.; Baer, A.D.; Finney, M.A.; Beckendorf, K.L.; Eidenshink, J.; $\mathrm{Zhu}, \mathrm{Z}$. Estimation of wildfire size and risk changes due to fuels treatments. Int. J. Wildland Fire 2012, 21, 357-367. [CrossRef]

20. Fischer, W.C.; Arno, S.F. Protecting people and homes from wildfire. In Proceedings of the Symposium and Workshop on Protecting People and Homes in the Interior West, Missoula, MT, USA, 6-8 October 1988; Volume 213. 
21. National Wildfire Foundation. The power of politics, the media and the public to affect wildland/urban fire protection programs in the 1990's. In Proceedings of the 1992 Symposium and Workshop Proceedings, Missoula, MT, USA, 21-25 April 1992; Volume 109, pp. 72-76.

22. Queen, P.L. Fighting Fire in the Wildland/Urban Interface; Fire Publications Inc.: Bellflower, CA, USA, 1993; Volume 115.

23. Slaughter, R. California's l-Zone: Urban/Wildland Fire Prevention and Mitigation; Slaughter, R., Ed.; CFESTES bookstore: Sacramento, CA, USA, 1996; Volume 301.

24. Salvati, L. Profiling forest fires along the urban gradient: A Mediterranean case study. Urban Ecosyst. 2014, 17, 1175-1189. [CrossRef]

25. Xanthopoulos, G. Particular difficulties in dealing suburban forest fires. Fire Rev. 2000, 80, 22. (In Greek)

26. Agee, J.K.; Skinner, C.N. Basic principles of forest fuel reduction treatments. For. Ecol. Manag. 2005, 211, 83-96. [CrossRef]

27. Agee, J.K.; Lolley, M.R. Thinning and prescribed fire effects on fuels and potential fire behavior in an eastern Cascades forest, Washington. Fire Ecol. 2006, 2, 3-19. [CrossRef]

28. Harrington, M.G.; Noonan-Wright, E.; Doherty, M. Testing the modeled effectiveness of an operational fuel reduction treatment in a small western Montana interface landscape using two spatial scales. In Proceedings of the Conference 'Fuels Management-How to Measure Success', Destin, FL, USA, 26-30 March 2007; pp. 301-314.

29. Horschel, E.A. Using NEXUS to Assess the Effectiveness of Experimental Black Spruce Forest Fuel Breaks to Reduce Fire Potential in Alaska; Independent Research; University of Alaska Fairbanks: Fairbanks, AK, USA, 2007.

30. Huggett, R.G.; Abt, K.L.; Shepperd, W. Efficacy of mechanical fuel treatment for reducing wildfire hazard. For. Policy Econ. 2008, 10, 408-414. [CrossRef]

31. Roccaforte, J.P.; Fule, P.Z.; Covington, W.W. Landscape-scale changes in canopy fuels and potential fire behaviour following ponderosa pine restorations treatments. Int. J. Wildland Fire 2008, 17, 293-303. [CrossRef]

32. Molina, J.R.; Rodriguez y Silva, F.; Herrera, M.A. Potential crown fire behaviour in Pinuspinea stands following different fuel treatments. For. Syst. 2011, 20, 266-277.

33. Finney, M.A. FARSITE: Fire Area Simulator-Model Development and Evaluation; Res. Pap. RMRSRP-4; U.S. Department of Agriculture, Forest Service, Rocky Mountain Research Station: Fort Collins, CO, USA, 1998; Volume 47.

34. Finney, M.A. An overview of FlamMap fire modeling capabilities. In Proceedings of the Fuels Management-How to Measure Success Conference, Portland, OR, USA, 28-30 March 2006; pp. 213-220.

35. Scott, J.H. NEXUS: A system for assessing crown fire hazard. Fire Manag. Notes 1999, 59, $20-24$.

36. Zagas, T.; Raptis, D.; Zagas, D.; Karamanolis, D. Planning and assessing the effectiveness of traditional silvicultural treatments for mitigating wildfire hazard in pine woodlands of Greece. Nat. Hazards 2013, 65, 545-561. [CrossRef]

37. Tsitsoni, T.; Raptis, D.; Zagas, D.; Zagas, T. Evaluating the effects of simulated silvicultural treatments and management on wildfire severity in Pinus halepensis Mill. even-aged stands. Curr. Environ. Eng. 2014, 1, 136-147. [CrossRef]

38. Piqué, M.; Domènech, R. Effectiveness of mechanical thinning and prescribed burning on fire behavior in Pinus nigra forests in NE Spain. Sci. Total Environ. 2017, 618, 1539-1546. [CrossRef] [PubMed]

39. Elia, M.; Lafortezza, R.; Lovreglio, R.; Sanesi, G. Developing Custom Fire Behavior Fuel Models for Mediterranean Wildland-Urban Interfaces in Southern Italy. Environ. Manag. 2015, 56, 754-764. [CrossRef] [PubMed]

40. Ottmar, R.D.; Vihnanek, R.E.; Wright, C.S. Stereo Photo Series for Quantifying Natural Fuels. Volume I: Mixed-Conifer with Mortality, Western Juniper, Sagebrush, and Grassland Types in the Interior Pacific Northwest; National Fire Equipment System Publication (NFES): Boise, Idaho, 1998; Volume 2580.

41. Lemmon, P.E. A spherical densiometer for estimating forest overstory density. For. Sci. 1956, 2, 314-320.

42. Mitsopoulos, I.D.; Dimitrakopoulos, A.P. Allometric equations for crown fuel biomass of Aleppo pine (Pinus halepensis Mill.) in Greece. Int. J. Wildland Fire 2007, 16, 642-645. [CrossRef]

43. Alexander, M.E. Help with making crown fire hazard assessments. In Proceedings of the Symposium and Workshop on Protecting People and Homes in the Interior West, Missoula, MT, USA, 6-8 October 1988; pp. 147-156. 
44. Fernades, P.M.; Loureiro, C.; Botelho, H.S. Fire behaviour and severity in a maritime pine stand under differing fuel conditions. Ann. For. Sci. 2004, 61, 537-544. [CrossRef]

45. Scott, J.H.; Burgan, R.E. Standard Fire Behavior Fuel Models: A Comprehensive Set for use with Rothermel's Surface Fire Spread Model; General Technical Report RMRS-GTR-153; USDA, Forest Service, Rocky Mountain Research Station: Fort Collins, CO, USA, 2005; Volume 72.

46. Dimitrakopoulos, A.P.; Papaioannou, K.K. Flammability assessment of Mediterranean forest fuels. Fire Technol. 2001, 37, 143-152. [CrossRef]

47. Fire Star. DB Particles ONLINE. Online database and management system of physical and chemical characteristics of fuel particles. In Fire Star: A Decision Support System for Fuel Management and Fire Hazard Reduction in Mediterranean Wildland-Urban Interfaces; Project No. EVG1-CT-2001-00041; European Commission: Brussels, Belgium, 2007.

48. Bacciu, V.M. Maquis Fuel Model Development to Support Spatially-Explicit Fire Modeling Applications. Ph.D. Thesis, Universita Degli Studi Di Sassari, Sassari, Italy, 2009.

49. Rothermel, R.C. A Mathematical Model for Predicting Fire Spread in Wildland Fuels; USDA Forest Service, Research Paper, INT-115; Intermountain Forest and Range Experiment Station: Ogden, UT, USA, 1972; Volume 40.

50. Rothermel, R.C. Predicting Behavior and Size of Crown Fires in the Northern Rocky Mountains; USDA Forest Service, Research Paper, INT-438; Intermountain Forest and Range Experiment Station: Ogden, UT, USA, 1991; Volume 46.

51. Van Wagner, C.E. Conditions for the start and spread of crown fire. Can. J. For. Res. 1977, 7, 23-24. [CrossRef]

52. Scott, J.H. Sensitivity analysis of a method for assessing crown fire hazard in the Northern Rochy Mountains, USA. In Proceedings of the III International Conference on Forest Fire Research and 14th Conference on Fire and Forest Meteorology, Luso, Portugal, 16-20 November 1998; Volume II, pp. 2517-2532.

53. Fule, P.Z.; McHugh, C.; Heinlein, T.A.; Covington, W.W. Potential fire behaviour is redused following forest restoration treatments. In Proceedings of the Symposium and Workshop on Ponderosa Pine Ecosystems Restoration and Conservation: Steps toward Stewardship, Flagstaff, AZ, USA, 25-27 April 2000; pp. $22-28$.

54. Cheyetee, D.; Rupp, S.T.; Rodman, S. Development Fire Behaviour, Fuel Models for the Wildland-Urban Interface in Anchorage, Alaska. West. J. Appl. For. 2008, 23, 149-155.

55. Silva, J.S.; Fernandes, P.A.M.; Vasconcelos, J. The effect on surface fuels and fire behavior of thinning a Pinuspinaster stand in central Portugal. In Proceedings of the Joint Fire Science Conference and Workshop on Crossing the Millennium: Integrating Spatial Technologies and Ecological Principles for a New Age in Fire Management, Boise, ID, USA, 15-17 June 1999; Volume II, pp. 275-277.

56. Scott, J.H.; Reinhardt, E.D. Assessing Crown Fire Potential by Linking Models of Surface and Crown Fire Behavior; Research Paper RMRS-RP-29; U.S. Department of Agriculture, Forest Service, Rocky Mountain Research Station: Fort Collins, CO, USA, 2001; pp. 1-66.

57. Loureiro, C.; Fernandes, P.; Botelho, H. A simulation-based test of a landscape fuel management project in the Maraõ range of northern Portugal. For. Ecol. Manag. 2006, 234-245. [CrossRef]

58. Keyes, C.R. Quantifying stand targets for silvicultural prevention of crown fires. West. J. Appl. For. 2002, 17, 101-109.

59. Agee, J.K. Fire strategies and priorities for forest health in the Western United States. In Proceedings of the Conference on Fire and Forest Meteorology, International Association of Wildland Fire, Fairfield, Lorne, Australia, 12-14 January 1998; pp. 297-303.

(C) 2018 by the authors. Licensee MDPI, Basel, Switzerland. This article is an open access article distributed under the terms and conditions of the Creative Commons Attribution (CC BY) license (http://creativecommons.org/licenses/by/4.0/). 